\title{
USO DA TECNOLOGIA NA EDUCAÇÃO TEATRAL PARA FORMAÇÃO CONTINUADA DE PROFESSORES DA REDE PÚBLICA DE ENSINO EM SÃO LUÍS- MARANHÃO
}

\section{RESUMO}

Face ao universo globalizado, onde a tecnologia está cada vez mais associada ao âmbito educacional, tem-se, então, a necessidade de formação de professores para estarem preparados a desenvolver atividades sob o uso das ferramentas a qual esta era da informação oferece. Destacamos no desenvolvimento deste projeto que no âmbito da educação teatral, diante os desdobramentos da atualidade, torna-se um desafio à formação dos professores sua inserção nas Tecnologias Digitais de Informação e Comunicação (TDICs), para que esses possibilitem meios aos processos de criação. E para que as TDICs possam ser usadas em sua potencialidade, é preciso, a priori, que os sujeitos envolvidos na esfera educacional repensem sobre a educação. A presença da tecnologia no teatro pode ser vista desde sua presença no teatro grego com o deus exmachine, perpassando os dispositivos cênicos da Idade Média, até a era da tecnologia digital hoje. Cabe ao professor de teatro, acompanhar o seu processo e evolução para aplicação em sala de aula. Segundo Castro e Oliveira (2016), a experiência estética embutida na arte digital está cada vez mais próxima do cotidiano dos sistemas escolares. Pensando nisso e mediante as problemáticas observadas durante o desenvolvimento deste projeto de pesquisa devido ao despreparo/desconhecimento para lidar com as potencialidades das TIDCs é que se tem como objetivo promover oficinas de formação continuada e fomentar a produção de práticas pedagógicas a partir de ferramentas que colaborem no processo de ensino-aprendizagem do teatro aos professores da rede pública de São Luís/MA. Assim como, discutir a inserção das tecnologias na prática docente e suas contribuições para o ensino teatral, explicitar recursos tecnológicos e suas possibilidades de uso e fomentar a produção de práticas pedagógicas a partir de ferramentas que colaborem na prática docente. Como metodologia foram elaboradas oficinas de formação continuada aos professores de teatro em escolas públicas de São Luís/MA, a partir de recursos tecnológicos sugeridos, entre eles hardwares (celular, tablet, computador/notebook) e softwares que colaborem com a criação teatral e o ensino-aprendizagem do aluno em sala de aula. Segundo Santaella (2009), referência no campo das tecnologias da comunicação e estéticas tecnológicas, 
as mídias apropriadas de nosso tempo são tecnologias digitais, memórias eletrônicas, hibridizações de ecossistemas com tecnossistemas, e o resultado deste desenvolvimento é uma crescente sobreposição das artes com a ciência. Dessa forma, para dar andamento às oficinas parte-se de uma abordagem metodológica qualitativa, no intuito de levar os professores a ensinar teatro na perspectiva das tecnologias contemporâneas, como uso de vídeo e outros multimeios aliados à educação e sua aplicação para o teatro. A etapa seguinte a essa, toma como base a formação básica do professor de teatro em seu fazer teatral e sua relação com as tecnologias.

Palavras-Chave: Tecnologia. Recursos Tecnológicos. Teatro. Educação. Professor.

Eixos temáticos: Mediação Teatral e Metodologias de Ensino 